\title{
In vitro Evaluation of Fungicides Plant Extracts and Bio-agents against Alternaria helianthi causing Leaf Blight of Sunflower
}

\author{
G. Mahadevaswamy ${ }^{1 *}$, G. Vijayalakshmi ${ }^{2}$ and G. Gangadharanaik ${ }^{1}$ \\ ${ }^{1}$ Department of Plant Pathology, University of Agricultural and Horticultural Sciences, \\ Shimoga, Karnataka, India - 577225 \\ ${ }^{2}$ Department of Plant Pathology, University of Agricultural Sciences, \\ Bengaluru -560065, India
}

*Corresponding author

\section{A B S T R A C T}

\begin{tabular}{|l|}
\hline K e y w o r d s \\
In-vitro evaluation, \\
Fungicides, Plant \\
extracts, Bio agents, \\
Alternaria helianthi \\
\hline Article Info \\
\hline Accepted: \\
14 January 2019 \\
Available Online: \\
10 February 2019 \\
\hline
\end{tabular}

\section{Introduction}

Sunflower (Helianthis annuus L.) belongs to the family Asteraceae and it is one of the most important edible oilseed crops in India. It is a hardy and an herbaceous annual, which grows up to a height of 5 feet. The word Helianthus is derived from Greek word 'Helios' (sun) and 'anthos' (flower).Presently in India Sunflower crop is cultivated in an area of 0.487 million hectares with a production of 296 MT and a productivity of $608 \mathrm{~kg} / \mathrm{ha}$

\begin{abstract}
Alternaria leaf blight of sunflower caused by Alternaria helianthi is an important disease of sunflower. The study conducted on in vitro evaluation of new molecules of fungicides and plant extracts against Alternaria helianthi, causal agent of Alternaria blight of sunflower. In vitro evaluation of fungicides revealed that, among four systemic fungicides hexaconazole and propiconazole were highly effective in inhibiting the mycelial growth with $100 \%$ inhibition among non systemic fungicides the maximum inhibition of mycelial growth was found in captan $(86.30 \%)$ at $600 \mathrm{ppm}$ concentration followed by copper oxy chloride $(84.07 \%)$ whereas, among the botanicals neem seed kernel extracts at 10 per nt $(43.74 \%)$ showed positive effect on inhibition of pathogen mycelium growth followed by neem leaf extracts(25.26\%). Trichoderma harzianum shows the best bio agents against Alternaria helianthi with highest per cent inhibition (72.48\%).
\end{abstract}


A study has been conducted at Department of Plant Pathology, College of Agriculture Navile, Shimoga to know the efficacy of systemic fungicides, non-systemic fungicides and leaf extracts (four each) against $A$. helianthi was assessed by following poison food technique. Both Systemic fungicides and non-systemic fungicides were evaluated at 100, 200, 400 and $600 \mathrm{ppm}$ concentrations and plant extracts were taken at 2.5, 5 and 10 percent each were evaluated. These were assessed by Poison food technique and the efficacy of the fungicides was expressed as per cent inhibition of mycelial growth over control, which was calculated by using the formula.

$\mathrm{I}=\frac{\mathrm{C}-\mathrm{T}}{\mathrm{C}} \times 100$

Where,

$\mathrm{I}=$ per cent inhibition

$\mathrm{C}=$ pathogen growth in control plate

$\mathrm{T}=$ pathogen growth in treatment plate

The plant extracts were prepared by grinding fresh leaves in a pestle and mortar by using sterile distilled water. The extract was filtered through double layered muslin cloth and made to the required concentration by adding distilled water.

The details of fungicides / plant extracts tested are given below.

\begin{tabular}{|c|l|l|}
\hline \multicolumn{2}{|l|}{ Non systemic fungicides } \\
\hline Sl. No. & Fungicides & $\begin{array}{l}\text { Trade } \\
\text { Name }\end{array}$ \\
\hline $\mathbf{1}$ & Captan 50 WP & Captaf \\
\hline $\mathbf{2}$ & Chlorothalonil 75 WP & Kavach \\
\hline $\mathbf{3}$ & $\begin{array}{l}\text { Copper oxy chloride } \\
\text { 50 WP }\end{array}$ & Blitox \\
\hline $\mathbf{4}$ & Mancozeb 75 WP & $\begin{array}{l}\text { Indofil M- } \\
45\end{array}$ \\
\hline
\end{tabular}

\begin{tabular}{|c|l|l|}
\hline \multicolumn{3}{|l|}{ Systemic fungicides } \\
\hline Sl. No. & Common Name & $\begin{array}{l}\text { Trade } \\
\text { Name }\end{array}$ \\
\hline 1 & $\begin{array}{l}\text { Carbendazim 50 } \\
\text { WP }\end{array}$ & Bavistin \\
\hline 2 & Hexaconazole 5 EC & Nectar \\
\hline 3 & $\begin{array}{l}\text { Propiconazole 25 } \\
\text { EC }\end{array}$ & Tilt \\
\hline 4 & $\begin{array}{l}\text { Thiophanate methyl } \\
75 W P\end{array}$ & Roko \\
\hline
\end{tabular}

\section{Preparation of cold aqueous extract}

Fresh plant materials were collected and washed first in tap water and then in distilled water. Hundred grams of fresh sample was chopped and then crushed in a surface sterilized pestle and mortar by adding $100 \mathrm{ml}$ sterile distilled water $(1: 1 \mathrm{w} / \mathrm{v})$. The extracts were filtered through two layers of muslin cloth and then through Whatman No. 1 filter paper. Finally filtrate thus obtained was used as stock solution. Nimbicidin as commercial formulation available in the market was used.

To study the compatibility as well the antifungal mechanism of plant extracts the poisoned food technique was used (Nene and Thapliyal, 1982). The efficacy of plant products or botanicals was expressed as per cent of radial growth/cfu over the control which was calculated using the formula (Vincent, 1947).

\begin{tabular}{|c|l|l|}
\hline \multicolumn{2}{|l|}{ Plant extracts } \\
\hline $\begin{array}{c}\text { Sl. } \\
\text { No. }\end{array}$ & Common Name & $\begin{array}{l}\text { Scientific } \\
\text { name }\end{array}$ \\
\hline 1 & $\begin{array}{l}\text { Neem seed } \\
\text { kernel extract }\end{array}$ & $\begin{array}{l}\text { Azadirachta } \\
\text { indica }\end{array}$ \\
\hline 2 & $\begin{array}{l}\text { Neem leaves } \\
\text { extract }\end{array}$ & $\begin{array}{l}\text { Azadirachta } \\
\text { indica }\end{array}$ \\
\hline 3 & $\begin{array}{l}\text { Kari jaali leaves } \\
\text { extract }\end{array}$ & $\begin{array}{l}\text { Prosopis } \\
\text { juliflora }\end{array}$ \\
\hline 4 & $\begin{array}{l}\text { Chromolina } \\
\text { leaves extract }\end{array}$ & $\begin{array}{l}\text { Chromolina } \\
\text { odonata }\end{array}$ \\
\hline
\end{tabular}




\section{Dual culture technique for bioagents}

Twenty $\mathrm{ml}$ of sterilized and cooled potato dextrose agar medium was poured into sterile Petri plates and allowed to solidify. For evaluation of fungal bio-control agents, mycelial discs of test fungus were inoculated at one end of the Petri plate and antagonistic fungus was placed opposite to it on the other end. In case of evaluation of bacterial antagonist, the bacterium was streaked one day earlier at one end of the Petri plate to the middle of the Petri plate and the test fungus placed at the other end. The plates were incubated at $27 \pm 1^{\circ} \mathrm{C}$ and zone of inhibition was recorded by measuring the clear distance between the margin of the test fungus and antagonistic organism. The colony diameter of pathogen in control plate was also recorded. The per cent inhibition of growth of the pathogen was calculated by using the formula suggested by Vincent (1947).

$\mathrm{I}=\frac{\mathrm{C}-\mathrm{T}}{\mathrm{C}} \times 100$

Where,

$\mathrm{I}=$ per cent inhibition

$\mathrm{C}=$ growth of pathogen in control

$\mathrm{T}=$ growth of pathogen in treated plate

\begin{tabular}{|c|l|}
\hline \multicolumn{2}{|l|}{ List of Bio agents used for study } \\
\hline Sl no & Bio agents \\
\hline 1 & Trichodermaviride (IIHR) \\
\hline 2 & T. harzianum(Local) \\
\hline 3 & $\begin{array}{l}\text { Pseudomonas fluorescens (local } \\
\text { strain) }\end{array}$ \\
\hline 4 & P. fluorescens (IIHR) \\
\hline
\end{tabular}

\section{Results and Discussion}

In vitro evaluation of fungicides against $A$. helianthi

Four non-systemic and four systemic fungicides were evaluated for their efficacy against $A$. helianthi by following poison food technique. The data are presented in Table 1 and 2.

Among different non systemic fungicides tested at $100 \mathrm{ppm}$ the highest inhibition of radial growth was recorded by Captan $(50.74 \%)$ which differed significantly from other fungicide tested Mancozeb and Chlorothlonil with an inhibition of 35.93 per cent and 29.63 percent respectively. Whereas, Copper oxychloride (17.41\%) recorded the least inhibition (Table 1). At 200 ppm Captan recorded the highest inhibition of colony radial growth by 80.86 per cent, followed by Copper oxy chloride $(51.48 \%)$ and the least inhibition was recorded in Chlorothlonil (35.74\%). The highest inhibition of radial growth of 80.86 percent was recorded with Captan at $400 \mathrm{ppm}$ which is superior and significantly differed from other fungicides tested, followed by Copper oxy chloride, Mancozeb with an inhibition of 64.44 per cent and 64.63 percent respectively and was on par with each other. At $600 \mathrm{ppm}$ Captan recorded the highest inhibition of radial growth of 50.74 per cent, which significantly differed from other fungicides tested, followed by Copper oxy chloride $(84.07 \%)$ and the least inhibition was recorded by Chlorothalonil (47.79\%) (Fig. 1).

Among different systemic fungicides tested at $100 \mathrm{ppm}$ the highest inhibition of radial growth was recorded by Hexaconazole (93.52\%), followed by Propiconazole (92.59\%) and were on par and significantly superior over other fungicides. Followed by Thiophanate methyl (22.41\%) and Carbendazim (18.15\%) (Table 2 and Fig. 2).

The 100 per cent inhibition of radial growth was recorded by Hexaconazole at $200 \mathrm{ppm}$ whereas; Propiconazole recorded the inhibition of 93.70 per cent, followed by the thiophanate methyl (34.07\%) and Carbendazim (24.63\%). 


\begin{tabular}{|c|c|c|c|c|c|}
\hline \multicolumn{6}{|c|}{ Table.1 In vitro evaluation of systemic fungicides against $A$. helianthi } \\
\hline \multirow[t]{2}{*}{ SL. No } & \multirow[t]{2}{*}{ Fungicides } & \multicolumn{4}{|c|}{ Per cent inhibition of Radial growth(mm) } \\
\hline & & 100 ppm & 200 ppm & 400 ppm & 600 ppm \\
\hline 1 & Carbendazim & 18.15 & 24.63 & 39.07 & 44.44 \\
\hline 2 & Thiophanate methyl & 22.41 & 34.07 & 40.37 & 46.11 \\
\hline 3 & Propiconazole & 92.59 & 93.7 & 100 & 100 \\
\hline 4 & Hexaconazole & 93.52 & 100 & 100 & 100 \\
\hline \multicolumn{2}{|r|}{ Mean } & 56.67 & 63.1 & 69.86 & 72.63 \\
\hline & \multicolumn{2}{|c|}{ S.Em \pm} & $\mathrm{CD}$ at $1 \%$ & $\mathrm{CD}$ at $5 \%$ \\
\hline & ungicides (F) & \multicolumn{2}{|c|}{0.29} & 1.11 & 0.92 \\
\hline \multicolumn{2}{|c|}{ concentrations $(\mathrm{C})$} & \multicolumn{2}{|c|}{0.29} & 1.12 & 3.57 \\
\hline \multicolumn{2}{|r|}{$\mathbf{F} \times \mathbf{C}$} & \multicolumn{2}{|c|}{0.58} & 2.24 & 7.16 \\
\hline
\end{tabular}

\begin{tabular}{|c|c|c|c|c|c|}
\hline \multicolumn{6}{|c|}{ Table.2 In vitro evaluation of non-systemic fungicides against $A$. helianthi } \\
\hline SL & \multirow[t]{2}{*}{ Fungicides } & \multicolumn{4}{|c|}{ Per cent inhibition of Radial growth(mm) } \\
\hline No & & 100 ppm & 200 ppm & 400 ppm & 600 ppm \\
\hline 1 & Mancozeb & 35.93 & 48.89 & 64.63 & 73.89 \\
\hline 2 & Captan & 50.74 & 80.56 & 85.56 & 86.3 \\
\hline 3 & Chlorothalonil & 29.63 & 35.74 & 39.07 & 47.59 \\
\hline 4 & Copper oxy chloride & 17.41 & 51.48 & 64.44 & 84.07 \\
\hline \multicolumn{2}{|r|}{ Mean } & 33.42 & 54.16 & 63.42 & 72.96 \\
\hline & \multicolumn{2}{|c|}{ S.Em \pm} & $\mathrm{CD}$ at $1 \%$ & $\mathrm{CD}$ at $5 \%$ \\
\hline & Fungicide (F) & \multicolumn{2}{|c|}{0.56} & 2.20 & 1.64 \\
\hline \multicolumn{2}{|c|}{ Concentrations (C) } & \multicolumn{2}{|c|}{0.56} & 2.19 & 6.34 \\
\hline \multicolumn{2}{|r|}{$\mathbf{F} \times \mathbf{C}$} & \multicolumn{2}{|c|}{1.13} & 4.39 & 12.67 \\
\hline
\end{tabular}

\begin{tabular}{|c|c|c|c|c|c|}
\hline \multicolumn{6}{|c|}{ Table.3 In vitro evaluation of plant extracts against $A$. helianthi } \\
\hline SL & \multirow[t]{2}{*}{ Plant extracts } & \multicolumn{3}{|c|}{ Per cent inhibition of radial growth(mm) } & \multirow[t]{2}{*}{ Mean } \\
\hline No & & $2.50 \%$ & $5 \%$ & $10 \%$ & \\
\hline 1 & Neem seed kernel extract & 22.78 & 33.89 & 43.74 & 33.47 \\
\hline 2 & Neem leaf extract & 11.67 & 19.44 & 25.26 & 18.75 \\
\hline 3 & Chromolina leaf extract & 6.74 & 19.33 & 22.93 & 16.37 \\
\hline 4 & Prosopis leaf extract & 10.56 & 16.11 & 23.89 & 16.85 \\
\hline & S.Em \pm & \multicolumn{3}{|c|}{$\mathrm{CD}$ at $1 \%$} \\
\hline & $\operatorname{lant} \operatorname{extracts}(\mathbf{P})$ & \multirow{2}{*}{\multicolumn{2}{|c|}{$\begin{array}{l}0.29 \\
0.29\end{array}$}} & & \\
\hline \multicolumn{2}{|c|}{ concentration $(\mathrm{C})$} & & & \multicolumn{2}{|c|}{1.13} \\
\hline \multicolumn{2}{|c|}{$\mathbf{P} \times \mathbf{C}$} & 0.58 & \multicolumn{3}{|c|}{2.27} \\
\hline
\end{tabular}




\begin{tabular}{|c|c|}
\hline \multicolumn{2}{|c|}{ Table.4 Efficacy of different bio-agents against A. helianthi under in vitro } \\
\hline Bio agents & $\begin{array}{c}\text { Per cent inhibition over } \\
\text { control }\end{array}$ \\
\hline Trichodermaviride & 60.81 \\
\hline T. harzianum & 72.48 \\
\hline Pseudomonas fluorescens (local strain) & 39.41 \\
\hline P. fluorescens (IIHR) & 36.31 \\
\hline S.Em \pm & 1.21 \\
\hline CD at 5\% & 3.96 \\
\hline
\end{tabular}

Fig. 1: In vitro evaluation of sy stemic fungicides against $A$. helianthi

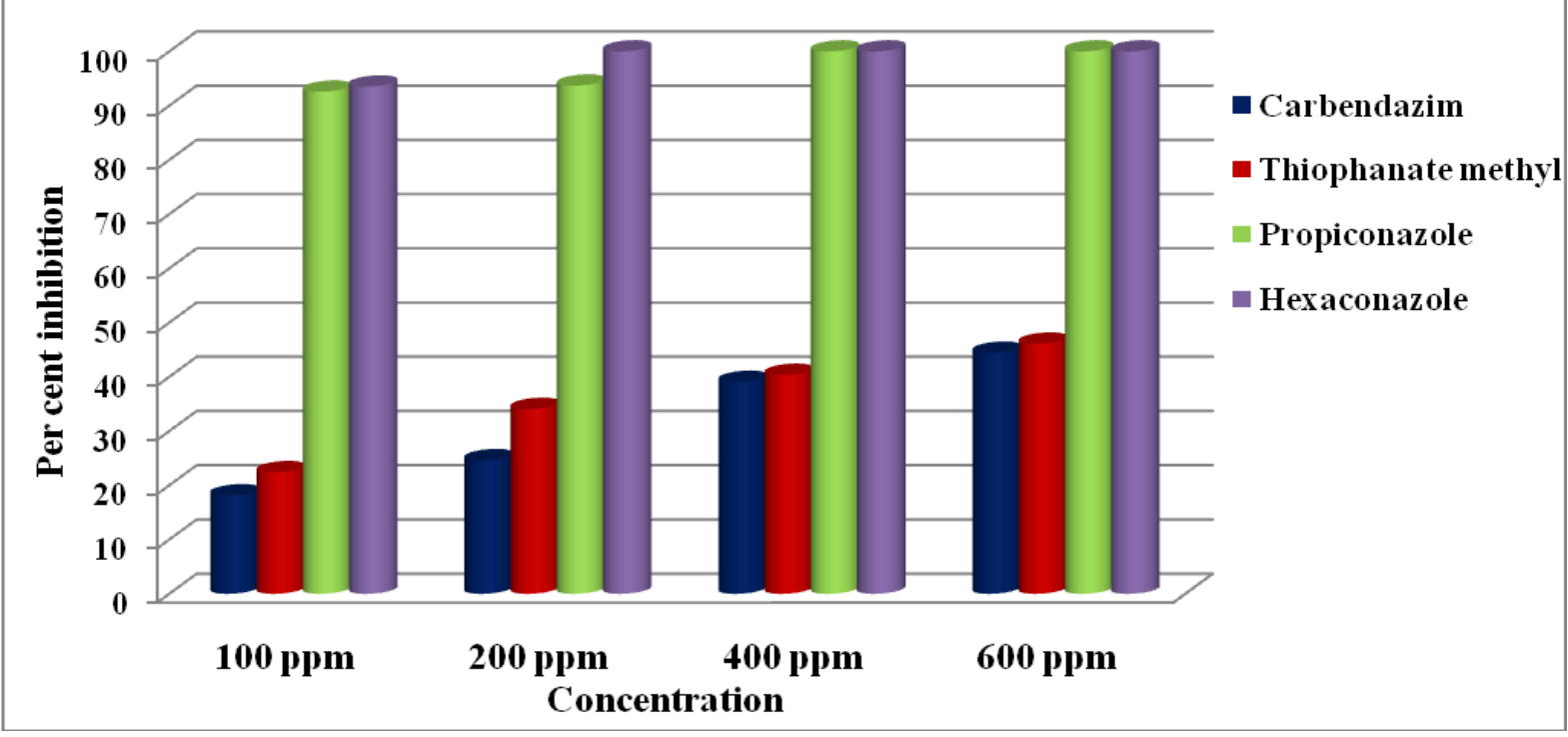

Fig. 2: In vitro evaluation of non sy stemic fungicides against $A$. helianthi

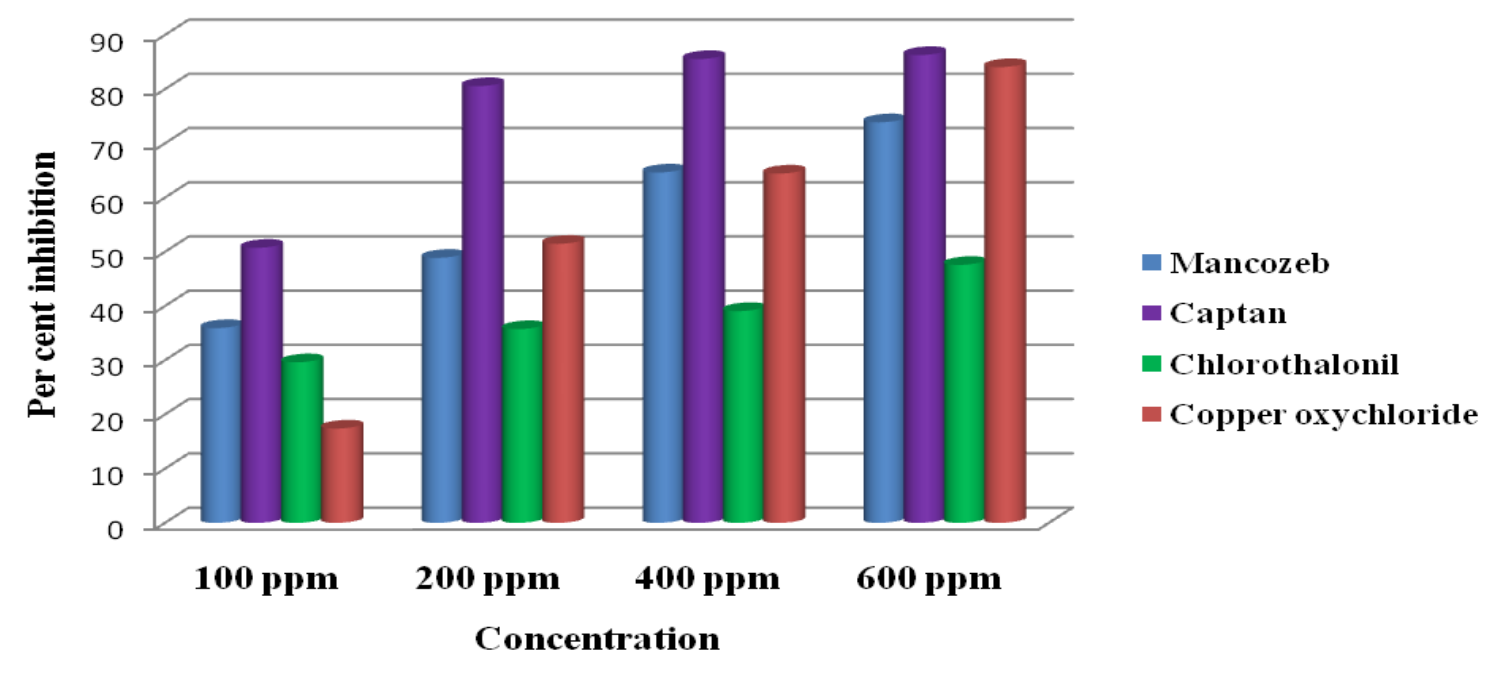



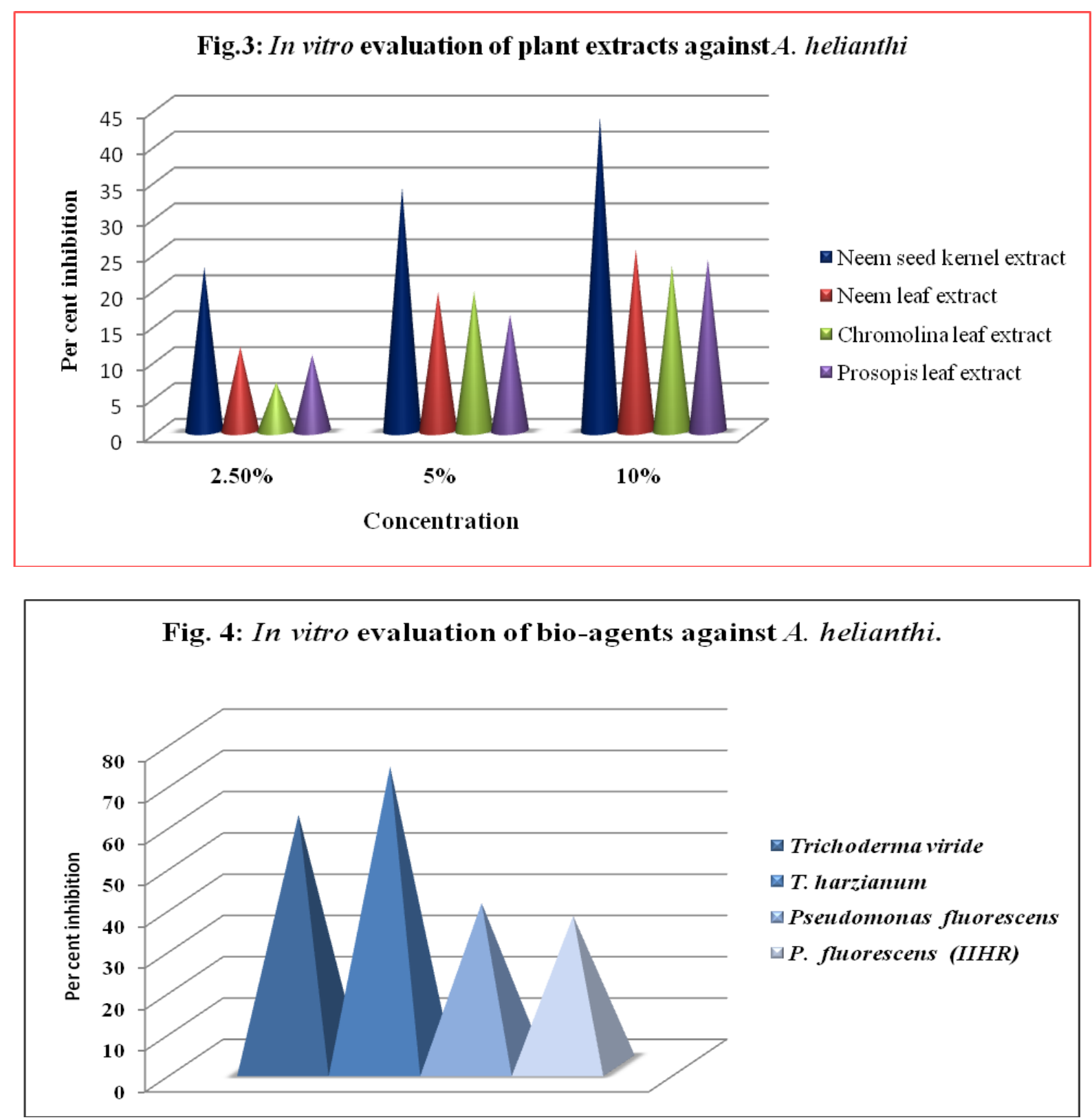

At 400 ppm, 100 percent inhibition of radial growth was observed with Hexaconazole and Propiconazole and these differed significantly compared to other fungicide tested.

These were followed by the Thiophanate methyl (40.37\%) and Carbendazim (39.07\%). At 600 ppm Hexaconazole and Propiconazole was found to be superior over other fungicides tested with 100 per cent inhibition of fungal radial growth followed by $\mathrm{COC}$ (84.07\%), Thiophanate methyl $(40.37 \%)$ and
Carbendazim (39.07\%). These results in conformity with the results of Mesta et al., (2009) reported that Hexaconazole (63.12\% and $72.87 \%$ respectively) and Propiconazole (61.80 and $76.53 \%$ ) were most effective and were found on par.

Thaware et al., (2010) reported that among different fungicides tested in vitro, Mancozeb (0.2 per cent) and Propiconazole (0.05 per cent) completely inhibited the growth of the test fungus. 
Chethana et al., (2012) recorded that Mancozeb and Propineb (0.3\%) caused 100 per cent inhibition of mycelia growth. This was also in confirmation with the work specified Vasudha et al., (2018) reported that Propiconazole (100\%) followed by Hexaconazole (99.38\%)

In vitro evaluation plant extracts against $A$. helianthi

As natural products isolated from plant appears to be one of the best alternatives in plant disease management as they are known to have minimal environmental impact and danger to consumers in contrast to synthetic pesticides. Among different plant extracts tested NSKE at 10 per cent showed maximum inhibition of 43.74 per cent, followed by Neem leaf extracts (25.26\%), karijaali (23.89\%) whereas, Chromolina leaf extract recorded the least $(22.93 \%)$ represented in Table 3 and figure 3 . At 5 per cent the maximum inhibition of 33.89 per cent was recorded by NSKE which significantly differed compared to others, followed by Neem leaf extracts $(19.44 \%)$ and karijaali leaf extracts $(16.11 \%)$. At 2.5 percent also the maximum inhibition was recorded with NSKE $(22.78 \%)$ and the least was inhibition was recorded by chromolina $(6.74 \%)$. The present study agrees with the findings of who observed, among the extract tested Neem seed kernel extract (NSKE) was found superior compared to other plant extracts tested against A. helianthi under in vitro condition.

\section{In vitro evaluation of bio-agents against $A$. helianthi}

From the observation it was revealed that, the maximum reduction in colony growth of $A$. helianthi was recorded in $T$. harzianum $(72.48 \%)$ treated plates which was significantly superior over all other bio-agents tested. However T. viride $(60.81 \%)$, Pseudomonas fluorescens $(39.41 \%)$ of local strain were also effective in inhibiting the growth of fungus. However the least inhibition of mycelia was noticed in Pseudomonas fluorescens (36.31\%) IIHR strain (Table 4 and Fig. 4).

These findings were in conformity with the observation made by Amaresh (2000), Chethana et al., (2012), Mesta (2006) and Kota (2003) reported that among the biocontrol agent $T$. viride and $T$. harzianum were effectively inhibited the growth of $A$. helianthi while the bacterium $P$. fluorescens produced maximum inhibition zone.

\section{References}

Amaresh, Y. S., 2000, Epidemiology and management of Alternaria leaf blight and rust of sunflower (Helianthus annus L.). Ph.D. Thesis, Univ. Agric. Sci. Dharwad, Pp. 320.

Anonymous, 2017, Food and Agriculture Organization (FAO) stat 2016-17.

Chethana B. S., Girija G, Archana, S. Rao,, Bellishree K (2012) In vitro evaluation of plant extracts, bioagents and fungicides against Alternaria porri (Ellis) Cif. causing purple blotch disease of onion. Pest Management in Horticultural Ecosystems, 18(2): 194198

Kota, V., 2003, Biological management of post-harvest fungal diseases of major fruits. M.Sc. (Agri) Thesis, Univ. Agric. Sci., Dharwad.

Mesta RK, Benagi VI, Srikant Kulkarni, ShankergoudI (2009). In vitro evaluation of fungicides and plant extracts against Alternaria helianthi causing blight of sunflower. Karnataka J. Agric. Sci., 22(1):111114.

Mesta, R. K., 2006, Epidemiology and management of Alternaria blight of sunflower caused by Alternaria 
helianthi (hansf.) Tubaki and Nishihara. PhD Thesis, Univ. Agric. Sci., Dharwad, p.181

Nene, Y. L. And Thapliyal, P. N., 1982, Fungicide in Plant Diseases Control, III (Edition: Oxford and IBH publishing Co. Pvt. Ltd., New Delhi, p. 325.

Thaware DS, Fugro PA, Jadhav YT, Magar SV, Karande RA (2010) In vitro evaluation of fungicide, plant extracts and bio-agents AGAINST Alternaria alternate (fr.) keissler causing leaf blight if cowpea. Int. J. Pl. Protect, 3(2):356-360.

Vasudha, A. K., Dhutraj, D.N., and Pawar, D.V. 2017. In vitro evaluation of different fungicides against Alternaria alternate causing leaf and fruit spot in pomegranate, Int. J. Curr. Microbiol. App. Sci. 7(10): 2292-2298

Vincent, J. M., 1947, Distortion of fungal hypae in the presence of certain inhibitors. Nature, 159: 239-241.

\section{How to cite this article:}

Mahadevaswamy, G., G. Vijayalakshmi and Gangadharanaik, G. 2019. In vitro Evaluation of Fungicides Plant Extracts and Bio-agents against Alternaria helianthi causing Leaf Blight of Sunflower. Int.J.Curr.Microbiol.App.Sci. 8(02): 1632-1639.

doi: https://doi.org/10.20546/ijcmas.2019.802.192 